\title{
Susi Ferfoglia
}

Uniwersytet Papieski Jana Pawta II w Krakowie

\section{Recenzja \\ Laus in Ecclesia. Szkota śpiewu gregoriańskiego. \\ Szkota św. Girzegorza, wstęp W. Ziótek, przekt. P. Wtodyga OSB, Dębogóra 2013}

Wszyscy, którym w Polsce leży na sercu sprawa chorału gregoriańskiego, mogą się cieszyć wydaną w 2013 roku książką Laus in Ecclesia. Szkota śpiewu gregoriańskiego, która jest przekładem polskim książki pod tym samym tytułem, wydanej rok wcześniej we Francji przez Schola Saint Grégoire (Szkoła św. Grzegorza). Autorem niniejszej książki, a właściwie podręcznika, jest nie jedna osoba, ale kilka osób skupionych wokół tejże szkoły, która ma swoją siedzibę w Le Mans w środkowej Francji. Osoby te swoje długoletnie poszukiwania i prace poświęciły zgłębianiu chorału gregoriańskiego rozumianego jako narzędzie ewangelizacji. Podręcznik jest zatem owocem tych doświadczeń i prezentuje nie tylko kompletny kurs śpiewu gregoriańskiego, ale także pewną jego interpretację, która za punkt wyjścia uznaje doświadczenie mnichów benedyktyńskich z Solesmes. Niezależnie od tego, czy ktoś się z tą metodą zgadza, czy nie, autorom niniejszej książki należy się wielki szacunek za wysiłek włożony w próbę usystematyzowania i przekazania metody Szkoły św. Grzegorza szerokiemu gronu odbiorców.

Książka napisana jest językiem przystępnym, jasnym, a sposób przekazywania wiedzy jest systematyczny, można wręcz powiedzieć: „dydaktyczny”. Tom składa się z 15 lekcji, a jego celem jest nauczenie śpiewania chorału według metody opracowanej przez benedyktyńskich mnichów z klasztoru Solesmes na przełomie XIX i XX wieku. Źródła tejże metody związane są z takimi nazwiskami, jak: o. Prosper Guéranger, o. Joseph Pothier, o. André Mocquereau oraz o. Joseph Gajard, którzy dali początek odnowie chorału gregoriańskiego nie tylko we własnym klasztorze, ale i w całym Kościele. Każda z 15 lekcji składa sie z kilku części. Część teoretyczna przekazuje wiedzę na temat zasad chorału gregoriańskiego (np. wiedza na temat neum, iktusu rytmicznego, wymowy, interpretacji); druga część poprzez wskazania i ćwiczenia prowadzi do nabycia umiejętności praktycznych, wokalnych lub rytmicznych; trzecia natomiast zawiera zadanie pisemne, przeznaczone do wykonania i przesłania do szkoły w celu zdania egzaminu i otrzymania dyplomu. Każda 
lekcja wzbogacona jest dodatkowo o materiały o charakterze duchowym i historycznym, które pomagają czytelnikowi głębiej i szerzej poznać historię i rozwój śpiewu gregoriańskiego. Cenną stroną podręcznika jest jego zakotwiczenie w nauce Kościoła. Częste przywoływanie tekstów Urzędu Nauczycielskiego Kościoła wprowadza czytelnika w samo serce troski Kościoła o jego śpiew i o jego piękno, rozumiane jako drogę do Boga. Do tomu dołączona jest również płyta CD nagrana przez benedyktynów z Fontgombault, która daje czytelnikowi możliwość „osłuchania się" i bezpośredniego wejścia w ducha chorału gregoriańskiego.

Fundamentalnym pojęciem w interpretacji śpiewu gregoriańskiego według metody zaprezentowanej w podręczniku jest iktus rytmiczny.

Iktus rytmiczny jest momentem, w którym ruch po wzniesieniu się zaczyna opadać. Jest to punkt łączący narastanie ze spoczynkiem, jednocześnie koniec ruchu i początek, liczenie na raz albo pierwszy raz (s. 111).

Możliwe jest zatem liczenie i określenie rytmu poszczególnych śpiewów. Rytm jest tą rzeczywistością

ukrytą, która zapewnia ciąłość linii melodycznej i nie jest zanotowana w nutach, a jest odpowiedzialna w dużej mierze za wspaniałą elastyczność melodii gregoriańskiej... Rytm jest tą rzeczywistością tajemniczą i głęboką, która ożywia melodię z jednej strony, a z drugiej zachowuje jej wewnętrzną spójność i scala całe bogactwo ekspresji sztuki muzycznej z modlitwą (s. 110).

Wielka teoria rytmiczna chorału gregoriańskiego jest wynikiem uważnego studiowania rękopisów, ale także obserwacji śpiewu mnichów przez o. Mocquereau, który opublikował ją w dwutomowym dziele Le nombre musical grégorien. Wierną uczennicą o. Mocquereau stała się Justine Ward, która opracowała metodę uczenia chorału gregoriańskiego począwszy od dzieci, skończywszy na dorosłych. Metoda ta leży u podstaw Szkoły św. Grzegorza założonej w roku 1938 przez Suzanne Bellin, która stała się też jej pierwszą dyrektorką. Metoda solesmeńska znalazła - jak widać - swoich zagorzałych zwolenników w osobach świeckich, które swoje życie poświęciły sprawie śpiewu kościelnego.

Niezwykle cenne wydaje mi się spojrzenie na chorał z punktu widzenia jego wewnętrznej duchowości. Metoda zaprezentowana w książce stawia za swój cel priorytetowy ukazanie chorału jako śpiewu wprowadzającego człowieka wyłącznie w sferę duchową. Śpiew gregoriański nie jest nigdy celem samym w sobie, ale wprowadza nas ciągle na nowo w tajemnicę Kościoła. 
Zatem śpiew gregoriański jako cel ma nie tyle wyrazić emocje, nawet nie, a przynajmniej nie tylko, wyrazić emocje człowieka wobec Boga, ale raczej wyrażać Bożą obecność w duszy człowieka i wewnętrznych zagięć duszy... Jego adresatem jest sam Bóg, a nie wierni... Takie podejście określa zasadniczą fizjonomię śpiewu gregoriańskiego, muzyki stworzonej wyłącznie po to, by wyrazić relacje między duszą a Bogiem. [...] Nie chodzi w nim o jakiś efekt, o spoglądanie na samego siebie; ma on służyć prowadzeniu duszy do Boga... Jest to postawa głębokiej pokory, adoracji, dziękczynienia, uwielbienia, ufności, nienaruszonego pokoju, który jest fundamentem każdego śpiewu gregoriańskiego. A nade wszystko miłość... (s. 277-278).

Oprócz tego książka w sposób systematyczny i niezwykle precyzyjny wprowadza w tajniki śpiewu gregoriańskiego, prowadząc czytelnika od początku, krok po kroku, poprzez poznawanie zapisu gregoriańskiego, jego tekstu oraz stylu. W ten sposób nawet osoby, które nie miały z tym śpiewem do czynienia, mogą dzięki cierpliwemu i wnikliwemu zgłębieniu przedstawionej metody wejść w „myślenie” chorałowe.

Niewątpliwie książka szczegółowo odpowiada na podstawowe pytania: czym jest śpiew gregoriański, jakie jest jego miejsce w Kościele, udzielając informacji teoretycznych, historycznych i duchowych. Wydaje mi się, że czytelnik nie może pozostać obojętnym wobec tematów w książce poruszonych; wręcz przeciwnie, ukazanie chorału przede wszystkim od strony duchowej otwiera przed człowiekiem podstawowe pytania: jaki jest nasz śpiew w Kościele? jak formujemy ludzi odpowiedzialnych za ten śpiew? co robimy, aby wychowywać ludzi, uwrażliwiając ich na to piękno, które może być drogą do Boga, a nie okazać się jedynie zaspokojeniem naszych doznań emocjonalno-zmysłowych? Trafne są w tym kontekście słowa Benedykta XVI, który powiedział, że naszą epokę charakteryzuje „moralność doznaniowa”. Oznacza to, że dobre jest to, co sprawia mi przyjemność, a złe, co przynosi przykrość. Nie można nie zauważyć tego, że muzyka kościelna często promuje takie style muzyczne, które bardziej odwołują się do niższych instynktów i wprowadzają pulsację rytmiczną, która ze sferą sakralną nie ma nic do czynienia. Chorał gregoriański wprowadza nas w inne „myślenie”; jego celem jest wyłącznie służba Boża. W jaki sposób to osiaga? Poprzez „jędrność” oraz poprzez „elastyczność" melodii. „Jędrność" linii melodycznej polega na wyłączeniu wszelkiej chromatyki, wielkich interwałów, na rytmie, który pełni rolę scalająca śpiew.

Jędrność służy uniknięciu przeszkód w modlitwie, którymi jest przesadny sentymentalizm, zbyt naturalna emocjonalność itd. Elastyczność natomiast tworzy z melodii gregoriańskiej narzędzie wewnętrznych i duchowych 
relacji między duszą a Bogiem. Ta elastyczność jest owocem modalności, rytmicznej wolności i melodycznej spontaniczności (s. 281).

Śpiew gregoriański uczy słuchania i patrzenia, bo trzeba wciąż słuchać i patrzeć na innych, trzeba w pewnym sensie zapomnieć o sobie, by osiągnąć wspólnotę serca i ducha, która wyraża się w jednogłosowym śpiewie. I to jest całe bogactwo chorału gregoriańskiego, bo jednogłosowość to nieustanne ćwiczenie się w miłości braterskiej, to troska, aby wszystkie głosy mogły brzmieć jako jeden głos, głos Kościoła. Ta jednogłosowość, która wydawać by się mogła pewnym ubóstwem tego śpiewu, staje się największym jego bogactwem wyrażającym tajemnicę Kościoła i jego Oblubieńca.

Serdecznie więc polecam książkę wszystkim, którzy w chorale gregoriańskim poszukują czegoś więcej niż fascynującej przygody intelektualnej, niż zaspokojenia zainteresowań historycznych i poznania dziedzictwa kulturowego i gotowi są stać się jak dziecko, które słucha, wpatruje się, przygląda, by móc otworzyć się na nieskończone piękno zawarte w dawnych melodiach chorałowych. 